Proceedings of the 34rd Meeting of the Association of Embryo Transfer in Europe (AETE); Nantes, France, September 7 th and 8 th, 2018.

\title{
Ovarian antral follicle populations and embryo production in cattle
}

\author{
Amanda Fonseca Zangirolamo ${ }^{1,2}$, Fabio Morotti ${ }^{1}$, Nathalia Covre da Silva ${ }^{1}$, Tamires Korchovei Sanches ${ }^{1}$, \\ Marcelo M. Seneda ${ }^{1,3}$

\begin{abstract}
${ }^{1}$ Universidade Estadual de Londrina, Laboratório de Reprodução Animal (DCV-CCA-UEL), Londrina, PR, Brazil. ${ }^{2}$ National Institute of Science and Technology for Dairy Production Chain (INCT-LEITE), Universidade Estadual de Londrina, Londrina, PR, Brazil.
\end{abstract}

\begin{abstract}
Reproductive biotechniques such as embryo production are important tools to increase the reproductive performance in cattle in a short time. In this context, the antral follicle count (AFC), which reflects the population of antral follicles present in an ovary, has been indicated as an important phenotypic characteristic related to female fertility and closely correlated to the performance of in vivo and in vitro embryo production (IVEP). A positive correlation was evidenced between AFC and oocyte retrieval by ovum pick up (OPU) sessions and and with the number of embryos produced. Several studies have reported that females with a high AFC had greater embryo yields compared to those with medium and low AFC. However, controversial results were obtained by studies conducted in different bovine breeds. Many conflicting data may be due to the differences in the experimental design, particularly regarding the classification of animals in AFC groups, subspecies particularities, herd aptitude or even issues related to animal management. Therefore, aspects such as the choice of donor, type of aspirated follicles and the stage of follicular wave need to be clarified. Thus, this text aims to discuss the use of AFC as a reproductive tool and its applications in the in vivo and in vitro production of embryos, besides describing consistent results and new challenges regarding AFC and embryo production.
\end{abstract}

Keywords: antral follicle count, Bos taurus, Bos indicus, cow, fertility.

\section{Introduction}

In the world scenario for bovine embryos, in the last decade, the in vitro embryo production (IVEP) has expanded remarkably when compared to in vivo embryo production (Watanabe et al., 2017). In the year 2016, a total of 666,215 in vitro embryos were produced, exceeding for the first time the volume of embryos produced in vivo (Perry, 2017). In this context, Brazil has contributed to the consolidation of large-scale application of this biotechnique and many challenges have been faced to improve the IVEP (Perry, 2016).

Several studies have been conducted to maximize the reproductive efficiency of the herd. In this way, the ovarian antral follicular count (AFC) as a tool to evaluate the ovarian reserve, has been positively correlated with parameters such as the number of viable oocytes, blastocyst (Santos et al., 2016) and conception rate after AI (Mossa et al., 2012). Different research groups investigated the embryo production performance of females with different AFC. This parameter is variable among females but highly constant in the same female (Burns et al., 2005; Morotti et al., 2017). For both indicus and taurus subspecies and indicus $\mathrm{x}$ taurus crossbred, a positive correlation was found between AFC and oocyte retrieval in the ovum pick up (OPU) sessions and the number of embryos produced in vitro (Ireland et al., 2008; Monteiro et al., 2017).

Considering embryonic production, females with high $\mathrm{AFC}$ presented a larger number of in vitro embryos when compared to those with low AFC (Ireland et al., 2008; Monteiro et al., 2017). Such information is quite predictable, considering that more follicles provide more oocytes to the in vitro embryo production. On other hand, the influence of AFC on the efficiency of embryonic production remains not well understood. For example, Rosa et al. (2018), reported no differences in both cleavage and blastocyst rates of oocytes that came from ovaries with different AFC. Also evaluating different AFC patterns, Rosa et al. (2018) evaluated the genes involved in oogenesis and folliculogenesis, which were differentially expressed in granulosa (progesterone receptor - PGR and Antimüllerian hormone receptor type II - AMHR2) and cumulus cells (natriuretic peptide receptor 2 and 3 NPR2/ NPR3, fibroblast growth factor 10 - FGF10 and signal transducer and activator of transcription 3 STAT3) from high versus low AFC cows. Mossa et al. (2010) reported lower abundance of cytochrome P450 family 17 subfamily A member 1 - CYP17A1 mRNA in thecal cells of low versus high AFC. Moreover, the study by Ireland et al. (2009) reported that the abundance of mRNAs for cytochrome P450 family 19 subfamily $A$ member 1 - CYP19A1 in granulosal cells and estrogen receptor 1 and 2 - ESR1/ ESR2, and cathepsin B - CTSB in cumulus cells were greater, whereas mRNAs for AMH in granulosal cells and TBCl domain family member 1 $T B C 1 D 1$ in thecal cells were lower for animals with low compared to the high AFC group during follicle waves.

Considering a general view on AFC, many points need to be addressed. For example, there is no standard to the classification of AFC according to the number of follicles. Comparing all the reports at the literature, it is easy to recognize several patters of AFC groups. In this way, it is quite difficult to compare data among the articles. Therefore, considering the importance of $\mathrm{AFC}$ on the embryo production this text aims to discuss: i) The use of AFC as a reproductive 
tool and the relationship between different fertility parameters (i.e. blastocyst rate and pregnancy, $\mathrm{AMH}$ concentration, among others); ii) applications of AFC on the in vivo and in vitro production of embryos and, iii) controversial data and new challenges regarding to the practical use of AFC as a reproductive tool for cattle.

\section{Use of $\mathrm{AFC}$ as a reproductive tool}

The association between reproductive biotechniques and genetic improvement programs in cattle has contributed to the development of the milk and food production (Hansen, 2014). The selection of females suitable for breeding is of great importance for reproductive efficiency, mainly because some ovarian physiological characteristics can directly influence the number and quality of oocytes (Lonergan et al., 1994). In this context, cows can be classified as low, intermediate or high AFC, according to the number of antral follicles (of $3 \mathrm{~mm}$ in diameter) detected via ovarian ultrasonography.

The AFC has been related to fertility parameters such as ovarian size, corpus luteum diameter, number of healthy oocytes, endometrial thickness, progesterone concentration, pregnancy rate and calving interval (Jimenez-Krassel et al., 2009, Martinez et al., 2016). Thus, considering the relationship between AFC and several characteristics linked to fertility, the selection of donors could be performed using a single ultrasound examination at the beginning of reproductive life (Silva-Santos et al., 2014; Morotti et al., 2017). Also, the Anti-mullerian hormone $(\mathrm{AMH})$, has been recognized as an indicator of ovarian response to superovulation protocols (Souza et al., 2015), being $\mathrm{AMH}$ also highly correlated to the AFC and viability of the oocytes (Baruselli et al., 2016). It was also observed a positive association between AMH and fertility in dairy cows (Jimenez-Krassel et al., 2015).

The AFC is a characteristic of low to moderate heritability, and it was verified that there is no correlation between AFC and milk production during lactation in Holstein cows (Walsh et al., 2014). Similarly, for Braford (beef) cattle, some parameters related to meat production showed low correlation with AFC (Morotti et al., 2017). Then, based on these studies, it can be suggested that AFC selection does not cause genetic demerit for the progeny.

In general, a greater number of antral follicles results in better OPU/IVEP quantitative efficiency. Many reports suggest that AFC is positively associated with the number of embryos produced by the donor in different breeds (Ireland et al., 2008; Silva-Santos et al., 2014, Santos et al., 2016). Although, more recently, Monteiro et al. (2017) did not find any advantage for Bos indicus females with high AFC relative to IVEP rates (Blastocyst rate $33.9 \%$ and $34.2 \%$ for low and high AFC animals, respectively).

In taurine females submitted to fixed time artificial insemination (FTAI) presenting high AFC, it was also found a higher pregnancy rate when compared to those with low AFC (94\% and 84\%, respectively; Mossa et al., 2012). In contrast, studies with indicine cattle did not find a positive correlation between AFC and pregnancy rates with artificial insemination (Mendonça et al., 2013; Santos et al., 2016). Surprisingly, an evaluation of AFC and timed artificial insemination showed better reproductive performance in low AFC Nelore cows than high AFC females (conception rate $61.7 \%$ and $49.5 \%$, respectively; Morotti et al., 2018). Recently, another unexpected result came from New Zealand with Bos taurus dairy cattle. The results showed that females with high AFC ( $\geq 25$ follicles) had suboptimal fertility and shorter productive life when compared to those with low AFC ( $\leq 15$ follicles) (Jimenez-Krassel et al., 2017). In contrast, also working with dairy cattle, Modina et al. (2014) had reported that those cows with intermediate number of antral follicles $(\mathrm{n}<10)$ were identified with reduction in the fertility parameters, when compared to females with $>10$ follicles. Once again, the comparison between the articles is quite difficult considering that AFC was not the single condition that was different in the experimental design. As pointed by Martinez et al. (2016), the associations of AFC with other fertility parameters need for further evaluations to ensure the best way to use this strategy on reproductive programs.

In conclusion, the relationship between AFC and fertility needs to be clarified. Both in Bos taurus and Bos indicus cattle have shown conflicting data, mainly when different approaches, embryo transfer - ET or artificial insemination - AI, have been considered.

\section{Applications of AFC for in vitro and in vivo production of embryos}

The embryo yield is highly variable in both in vitro and in vivo embryo production systems (Pontes et $a l ., 2010)$. The IVP may be affected by oocyte recovery rate on OPU, as well as ET is affected by the response of the donor afterthe superovulation protocol (SOV) (Ireland et al., 2007; Silva-Santos et al., 2014). Therefore, it is interesting to consider that the success of these techniques is dependent on the individual ovarian characteristics of the donor, which may affect the number and quality of the oocytes / embryos that are recovered (Stojsin-Carter et al., 2016).

In 2007, Ireland and collaborators performed a study with Bos taurus cattle and observed that the number of IVF embryos per animal in the high AFC group ( $\geq 25$ follicles) was four times higher $(\mathrm{P}<0.05)$ than the low AFC group $(\leq 15$ follicles $)$. In the multiple ovulation and embryo transfer (MOET), the number of embryos recovered after artificial insemination was $10.6 \pm 2.7 v s .4 .7 \pm 0.7$ for the high and low AFC group, respectively $(\mathrm{P}<0.05)$.

Similarly, indicus-taurus donors with high AFC ( $\geq 40$ follicles), produced a higher $(\mathrm{P}<0.05)$ number of blastocysts than animals of low AFC group ( $\leq 10$ follicles) both in IVF and MOET approaches (Silva-Santos et al., 2014). However, the same team reported less consistent results for Bos indicus cattle. The high AFC showed better embryo production performance, but the cleavage rate was similar among low ( $\leq 7$ follicles), intermediate ( 18 to 25 follicles) and high AFC ( $\geq 40$ follicles) (Santos et al., 2016).

The relationship between of the ovarian pool of follicles and the response to the superovulation has been 
previously evaluated (Cushman et al., 1999). However, possible applications of AFC and specific protocols to $\mathrm{SOV}$ is topic that remains to be better understood.

Considering $\mathrm{AFC}$ and genes related to folliculogenesis and oogenesis, it was reported differences in gene expression in cumulus and granulosa cells collected from Nelore cows with low and high AFC. Interestingly, in the study by Rosa et al. (2018), animals com high AFC had genes upregulated in granulosa cells while cows with a low AFC presented genes upregulated only in cumulus cells. Taking together with data from other studies, these findings suggest that AFC may influence the molecular network that controls ovarian function (Ireland et al., 2009; Mossa et al., 2010). Considering the importance of communications between oocyte and cumulus cells, as well as the influence of gonadotropins on the cAMP in the two cell types
(Luciano et al., 2004), it is quite predictable that AFC may really interfere on the rates of embryonic production. However, a precise experiment to consider only AFC and embryo production remains a challenge, since multiple aspects need to be isolated in the experimental design.

As described in Table 1, the main problem for comparing the AFC data is the classification of animals in groups of high and low AFC. Each team considered a specific strategy. Thus, it is quite difficult to compare the results.

Controversial data among studies in AFC classification also are present in both in vivo and in vitro embryonic production, as shown in Table 2.

Considering data of pregnancy rate and AFC after artificial insemination, it is also interesting to identify the clear differences among the groups, as shown in the Table 3 .

Table 1. Results (mean $\pm \mathrm{SD}$ ) from studies comparing in vitro embryo production in Bos taurus, Bos indicus and Bos indicus-taurus (crossbred) between high and low AFC groups.

\begin{tabular}{|c|c|c|c|c|c|c|c|}
\hline Author & type & AFC & $\begin{array}{c}\text { Animals } \\
\mathrm{n}\end{array}$ & $\begin{array}{c}\mathrm{PU} \\
\mathrm{n}\end{array}$ & $\begin{array}{c}\text { COC's } \\
n\end{array}$ & $\begin{array}{c}\text { Blastocyst } \\
\mathrm{n}\end{array}$ & $\begin{array}{c}\text { Blastocyst } \\
\text { rate } \%\end{array}$ \\
\hline \multirow[t]{2}{*}{ Ireland et al., 2007} & Bos taurus & $\begin{array}{c}\text { Low } \\
(\leq 15 \text { follicles })\end{array}$ & $68 * * *$ & --- & $7.5^{\mathrm{a}}$ & $1.3^{\mathrm{a}}$ & 29.6 \\
\hline & & $\begin{array}{c}\text { High } \\
(\geq 25 \text { follicles })\end{array}$ & $37 * * *$ & --- & $29.5^{\mathrm{b}}$ & $4.9^{\mathrm{b}}$ & 30.9 \\
\hline \multirow[t]{2}{*}{ Silva-Santos et al., 2014} & Bos indicus-taurus & $\begin{array}{c}\text { Low } \\
(\leq 10 \text { follicles })\end{array}$ & $20^{*}$ & 20 & $5.8 \pm 3.4^{\mathrm{A}}$ & $0.5 \pm 0.8^{\mathrm{A}}$ & $9.5^{\mathrm{A}}$ \\
\hline & & $\begin{array}{c}\text { High } \\
(\geq 40 \text { follicles })\end{array}$ & $20 *$ & 20 & $36.9 \pm 13.7^{\mathrm{B}}$ & $6.1 \pm 4.5^{\mathrm{B}}$ & $16.5^{\mathrm{B}}$ \\
\hline \multirow[t]{2}{*}{ Santos et al., 2016} & Bos indicus & $\begin{array}{c}\text { Low } \\
(\leq 7 \text { COC's) }\end{array}$ & $19^{*}$ & 19 & $3.8 \pm 1.1^{\alpha}$ & $0.6 \pm 0.6^{\alpha}$ & $13.0^{\alpha}$ \\
\hline & & $\begin{array}{c}\text { High } \\
(\geq 40 \text { COC's) }\end{array}$ & $22 *$ & 22 & $40.4 \pm 10.6^{\beta}$ & $18.4 \pm 6.7^{\beta}$ & $41.9^{\beta}$ \\
\hline \multirow[t]{2}{*}{ Monteiro et al., 2017} & Bos indicus & $\begin{array}{c}\text { Low } \\
(<15 \text { COC's })\end{array}$ & $18^{* *}$ & 216 & $10.8 \pm 0.4$ & $3.6 \pm 0.2$ & 33.9 \\
\hline & & $\begin{array}{c}\text { High } \\
(\geq 15 \text { COC's }) \\
\end{array}$ & $18^{* *}$ & 216 & $21.2 \pm 1.0$ & $7.1 \pm 0.4$ & 34.2 \\
\hline \multirow[t]{2}{*}{ Rosa et al., 2018} & Bos indicus & $\begin{array}{c}\text { Low } \\
\text { ( } \leq 31 \text { follicles) }\end{array}$ & $356 * * *$ & --- & 536 (total) & 203 (total) & 38.6 \\
\hline & & $\begin{array}{c}\text { High } \\
\text { ( } \geq 92 \text { follicles) }\end{array}$ & $356^{* * *}$ & --- & 617 (total) & 251 (total) & 40.6 \\
\hline
\end{tabular}

*Animals submitted to OPU only once. **Animals submitted to OPU more than once. ***Animals submitted to postmortem ovarian aspiration. ${ }^{\mathrm{a}, \mathrm{b} / \mathrm{A}, \mathrm{B} / \alpha, \beta}$ For the same author and variable were different $(\mathrm{P} \leq 0.05)$ between the AFCs groups. Adapted from Ireland et al. (2007); Silva-Santos et al. (2014); Santos et al. (2016); Monteiro et al. (2017) and Rosa et al. (2018).

Table 2. Results (mean $\pm \mathrm{SD}$ ) from studies comparing in vivo embryo production in Bos taurus and Bos indicustaurus (crossbred) between high and low AFC groups.

\begin{tabular}{|c|c|c|c|c|}
\hline Author & Animals & Number of follicles & Number of flushes & $\begin{array}{c}\text { Transferable embryos/ } \\
\text { animals }\end{array}$ \\
\hline \multirow[t]{2}{*}{ Ireland et al., 2007} & Bos taurus & $\begin{array}{c}\text { Low } \\
\text { ( } \leq 15 \text { follicles) }\end{array}$ & $21 *$ & $3.8 \pm 0.8^{\mathrm{a}}$ \\
\hline & & $\begin{array}{c}\text { High } \\
(\geq 25 \text { follicles })\end{array}$ & $19^{*}$ & $5.4 \pm 1.3^{\mathrm{b}}$ \\
\hline \multirow[t]{2}{*}{ Silva-Santos et al., 2014} & Bos indicus-taurus & $\begin{array}{c}\text { Low } \\
(\leq 10 \text { follicles })\end{array}$ & $20 * *$ & $1.9 \pm 2.1^{\mathrm{A}}$ \\
\hline & & $\begin{array}{c}\text { High } \\
\text { ( } \geq 40 \text { follicles) }\end{array}$ & $20 * *$ & $6.9 \pm 5.3^{\mathrm{B}}$ \\
\hline
\end{tabular}

*The same female may have been superovulated and collected up to twice. $* *$ One single collection per animal. ${ }^{a, b / A, B}$ For the same author were different $(\mathrm{P} \leq 0.05)$ between the AFCs groups. Adapted from Ireland et al. (2007) and Silva-Santos et al. (2014). 
Zangirolamo et al. Antral follicle populations and embryo production.

Table 3. Reproductive performance of females with high or low follicle count (AFC) after artificial insemination. Author Group Pregnancy rate $(\%)$

\begin{tabular}{lcc}
\hline \multirow{2}{*}{ Mossa et al., 2012} & Low AFC $(\leq 15$ follicles $)$ & 84 \\
\cline { 2 - 3 } & High AFC $(\geq 25$ follicles $)$ & 94 \\
\hline Mendonça et al., 2013 & Low $(\leq 12$ follicles $)$ & 51.85 \\
\cline { 2 - 3 } & High AFC $(\geq 30$ follicles $)$ & 44.73 \\
\hline Santos et al., 2016 & Low AFC $(\leq 10$ follicles $)$ & 58,6 \\
\cline { 2 - 3 } & High AFC $(\geq 25$ folículos $)$ & 51,9 \\
\hline
\end{tabular}

Adapted from Mossa et al. (2012); Mendonça et al. (2013) and Santos et al. (2016).

\section{AFC: consistent data versus new challenges}

The strategy used to the classification of females in AFC categories is very different in each author. Each one exhibited a distinct experimental design; some studies did not consider the AFC intermediate group or, for example, the oocytes were recovered in different ways - by OPU or ovaries from a slaughterhouse (Ireland et al., 2008; Monteiro et al., 2017). In some cases, the parameters used to classify females in AFC categories differed considerably among authors (Morotti et al., 2015). Therefore, when comparing studies concerning AFC, we should consider how the separation of animals into the categories was made, trying to establish a more balanced comparison.

Moreover, there are differences between the studied subspecies inherent to the physiology of the estrous cycle, which encompass divergences from follicular wave number per cycle to the number of follicles recruited per growth wave (Baruselli et al., 2007). For example, Holstein cows tend to present the predominance of two or three waves of follicular growth per estrus cycle (Ginther et al., 1989; Wolfenson et al., 2004), whereas Zebu cows are more related to three to four waves per estrus cycle (Rhodes et al., 1995; Nelore - Figueiredo et al., 1997). Also, Bos indicus females recruit more follicles per follicular growth wave than Bos taurus females $(33,4 \pm 3,2$ vs 25,4 $\pm 2,5$; Carvalho et al., 2008). Taking those data together, it is easy to realize the challenge to compare studies that present results of distinct subspecies. So, the comparison of AFC with fertility in different breeds should be studied individually.

Furthermore, for a better precision of the factors that interfere with AFC, it is necessary to consider the development phase in which the follicles are aspirated since there is a direct interference on the oocyte competence for IVEP. In this context, Cavalieri et al. (2018), showed that cows submitted to follicular wave synchronization had a better IVEP rate and pregnancy rate after ET when compared to females aspirated on a random day of estrous cycle. Because of that, the strategy for oocyte recovery must be considered when comparing different AFC cows.

In addition to the subspecies, it is also important to consider the influence of the age of the females in the AFC studies, since there are indications, that the ovarian follicular reserve decreases after the female reaches five years, suggesting a decrease in fertility (Cushman et al., 2009). The same authors also reported the importance of birth weight as a parameter that influences AFC, but the stage of estrous cycle seems to not interfere in the AFC classification, which facilitates the establishment of pattern (high, intermediate or low AFC) to each cow (Cushman et al., 2009).

In summary, according to the literature and data cited above, AFC seems to be correlated with several fertility parameters, and it may be a tool that can contribute to the success of embryo production both in vivo and in vitro. However, there is a great need to study the real long term impact of AFC on fertility, to establish specific parameters of AFC classification and to understand the physiological causes of the variation in the AFC among individual female cattle.

\section{Final comments}

Despite many studies on antral follicle population, the relationship between AFC, fertility, and efficiency of biotechniques are not fully understood. However, in the context of embryo production, the AFC can be used as an auxiliary tool for the selection of animals with the greater quantitative potential of embryos. Finally, a better understanding of the factors linked to AFC and of the reproductive characteristics from Bos indicus and Bos taurus may provide adjustments in cattle management and to improve the efficiency of reproductive biotechniques.

\section{References}

Baruselli PS, Gimenes LU, Sales JNS. 2007. Fisiologia reprodutiva de fêmeas taurinas e zebuínas. Rev Bras Reprod Anim, 31:205-211.

Baruselli PS, Batista EOS, Ferreira RM. 2016. Plasma anti-müllerian hormone allows reproductive selection of donors with greater potential of embryo production. Spermova, 6:1-13.

Burns DS, Jimenez-Krassel F, Ireland JLH, Knight PG, Ireland JJ. 2005. Numbers of antral follicles during follicular waves in cattle: evidence for high 
variation among animals, very high repeatability in individuals, and an inverse association with serum follicle-stimulating hormone concentrations. Biol Reprod, 73:53-62.

Carvalho JBP, Carvalho NAT, Reis EL, Nichi M, Souza AH, Baruselli PS. 2008. Effect of early luteolysis in progesterone-based timed AI protocols in Bos indicus, Bos indicus x Bos taurus, and Bos taurus heifers. Theriogenology, 69:167-175.

Cavalieri FLB, Morotti F, Seneda MM, Colombo AHB, Andreazzi MA, Emanuelli IP, Rigolon LP. 2018. Improvement of bovine in vitro embryo production by ovarian follicular wave synchronization prior to ovum pick-up. Theriogenology, 57:70-117.

Cushman RA, DeSouza JC, Hedgpeth VS, Britt JH. 1999. Superovulatory response of one ovary is related to the micro-and macroscopic population of follicles in the contralateral ovary of the cow. Biol Reprod, 60:349354.

Cushman RA, Allan MF, Kuehn LA, Snelling WM, Cupp AS, Freetly HC. 2009. Evaluation of antral follicle count and ovarian morphology in crossbred beef cows: Investigation of influence of stage of the estrous cycle, age, and birth weight. J Anim Sci, 87:1971-1980.

Figueiredo RA, Barros CM, Pinheiro OL, Sole JMP. 1997. Ovarian follicular dynamics in Nelore breed (Bos indicus) cattle. Theriogenology, 47:1489-1505.

Ginther OJ, Knopf L, Kastelic JP. 1989. Temporal associations among ovarian events in cattle during oestrous cycles with two or three follicular waves. $J$ Reprod Fertil, 87:223-230.

Hansen P. 2014. Current and Future Assisted Reproductive Technologies for Mammalian Farm Animals. Adv Exp Med Biol, 752:1-22.

Ireland JJ, Ward F, Jimenez-Krassel F, Ireland JLH, Smith GW, Lonergan P, Evans ACO. 2007. Follicle numbers are highly repeatable within individual animals but are inversely correlated with FSH concentrations and the proportion of good-quality embryos after ovarian stimulation in cattle. Hum Reprod, 22:1687-1695.

Ireland JLH, Scheetz D, Jimenez-Krasse F, Themmen APN, Ward F, Lonergan P, Smith GW, Perez GI, Evans ACO, Ireland JJ. 2008. Antral follicle count reliably predicts number of morphologically healthy oocytes and follicles in ovaries of young adult cattle. Biol Reprod, 79:1219-1225.

Ireland JJ, Zielak-Steciwko AE, Jimenez-Krassel F, Folger J, Bettegowda A, Scheetz D, Walsh S, Mossa F, Knight PG, Smith GW, Lonergan P, Evans ACO. 2009. Variation in the Ovarian Reserve Is Linked to Alterations in Intrafollicular Estradiol Production and Ovarian Biomarkers of Follicular Differentiation and Oocyte Quality in Cattle. Biol Reprod, 80:954-964.

Jimenez-Krassel F, Folger JK, Ireland JLH, Smith GW, Hou X, Davis JS, Lonergan P, Evans ACO, Ireland JJ. 2009. Evidence that high variation in ovarian reserves of healthy young adults has a negative impact on the corpus luteum and endometrium during estrous cycles in cattle. Biol Reprod, 80:1272-1281.

Jimenez-Krassel F, Scheetz DM, Neuder LM, Ireland JLH, Pursley JR, Smith GW, Tempelman
RJ, Ferris T, Roudebush WE, Mossa F, Lonergan P, Evans, ACO, Ireland JJ. 2015. Concentration of antiMüllerian hormone in dairy heifers is positively associated with productive herd life. $J$ Dairy $S c i$, 98:3036-3045.

Jimenez-Krassel F, Scheetz DM, Neuder LM, Pursley JR, Ireland JJ. 2017. A single ultrasound determination of $\geq 25$ follicles $\geq 3 \mathrm{~mm}$ in diameter in dairy heifers is predictive of a reduced productive herd life. J Dairy Sci, 100:5019-5027.

Lonergan P, Monaghan P, Rizos D, Boland MP, Gordon I. 1994. Effect of follicle size on bovine oocyte quality and development competence following maturation, fertilization and culture in vitro. Mol Reprod Dev, 37:48-53.

Luciano AM, Modina S, Vassena R, Milanesi E, Lauria A, Gandolfi F. 2004. Role of intracellular cyclic adenosine '3 5' -monophosphate concentration and oocyte-cumulus cells communications on the acquisition of the developmental competence during in vitro maturation of bovine oocyte. Biol Reprod, 70:465472.

Martinez MF, Sanderson N, Quirke LD, Lawrence SB, Juengel JL. 2016. Association between antral follicle count and reproductive measures in New Zealand lactating dairy cows maintained in a pasturebased production system. Theriogenology, 85:466-475.

Mendonça HGR, Santos GMG, Silva-Santos KC, Barreiros TRR, Blaschi W, Morotti F, Moraes FLZ, Seneda MM. 2013. Pregnancy rates following FTAI of Nelore heifers (Bos indicus) with high, intermediate and low numbers of antral follicles. Anim Reprod, 10:452.

Modina SC, Tessaro I, Lodde V, Franciosi F, Corbani D, Luciano AM. 2014. Reductions in the number of mid-sized antral follicles are associated with markers of premature ovarian senescence in dairy cows. Reprod Fertil Dev, 26:235-244.

Monteiro FM, Batista EOS, Vieira LM, Bayeux BM, Accorsi M, Campanholi SP, Dias EAR, Souza AH, Baruselli PS. 2017. Beef donor cows with high number of retrieved COC produce more in vitro embryos compared with cows with low number of COC after repeated ovum pick-up sessions. Theriogenology, 90:54-58

Morotti F, Barreiros TRR, Machado FZ, González SM, Marinho LSR, Seneda MM. 2015. Is the number of antral follicles an interesting selection criterium for fertility in cattle? Anim Reprod, 12:479-486.

Morotti F, Santos GMG, Koetz Júnior C, SilvaSantos KC, Roso VM, Seneda MM. 2017. Correlation between phenotype, genotype and antral follicle population in beef heifers. Theriogenology, 91:21-26.

Morotti F, Moretti R, Santos GMG, Silva-Santos KC, Cerqueira PH, Seneda MM. 2018. Ovarian follicular dynamics and conception rate in Bos indicus cows with different antral follicle counts subjected to timed artificial insemination. Anim Reprod Sci, 188:170-177.

Mossa F, Jimenez-Krassel F, Folger JK, Ireland JHL, Smith GW, Lonergan P, Evans ACO, Ireland JJ. 2010. Evidence that high variation in antral follicle count during follicular waves is linked to alterations in 
ovarian androgen production in cattle. Reproduction, 140:713-720.

Mossa F, Walsh SW, Butler ST, Berry DP, Carter F, Lonergan P, Smith GW, Ireland JJ, Evans ACO. 2012. Low numbers of ovarian follictes $3 \mathrm{~mm}$ in diameter are associated with low fertility in dairy cows J Dairy Sci, 95:2355-2361.

Perry G. 2016. Statistics of embryo collection and transfer in domestic farm animals. Embryo Technology Newsletter, 34:1-75.

Perry G. 2017. Statistics of embryo collection and transfer in domestic farm animals. Embryo Technology Newsletter, 35:1-46.

Pontes JHF, Silva KCF, Basso AC, Rigo AG, Ferreira CR, Santos GMG, Sanches BV, Porcionato JPF, Vieira PHS, Faifer FS, Sterza FAM, Schenk JL, Seneda MM. 2010. Large-scale in vitro embryos production and pregnancy rates from Bos taurus, Bos indicus, and indicus-taurus dairy cows using sexed sperm. Theriogenology, 74:1349-1355.

Rhodes FM, De'ath G, Entwistle KW. 1995. Animal and temporal effects on ovarian follicular dynamics in Brahman heifers. Anim Reprod Sci, 38-265-277.

Rosa CO, Marinho LSR, Da Rosa PRA, De Cesaro MP, Lunardelli PA, Santos KCS, Basso AC, Bordignon V, Seneda MM. 2018. Molecular characteristics of granulosa and cumulus cells and oocyte competence in Nelore cows with low and high numbers of antral follicles. Reprod Domest Anim, 53:921-929.

Santos GMGD, Silva-Santos KC, Barreiros TRR, Morotti F, Sanches BV, de Moraes FLZ, Blaschi W, Seneda MM. 2016. High numbers of antral follicles are positively associated with in vitro embryo production but not the conception rate for FTAI in Nelore cattle. Anim Reprod Sci, 165:17-21.
Silva-Santos KC, Santos GMG, Koetz Júnior C, Morotti F, Siloto LS, Marcantonio TN, Urbano MR, Oliveira RL, Lima DCM, Seneda MM. 2014. Antral follicle populations and embryo production - in vitro and in vivo - of Bos indicus-taurus donors from weaning to yearling ages. Reprod Domest Anim, 49:228-232.

Souza AH, Carvalho P, Rozner A, Vieira L, Hackbart K, Bender R, Dresch A, Verstegen J, Shaver R, Wiltbank M. 2015. Relationship between circulating anti-Müllerian hormone (AMH) and superovulatory response of high-producing dairy cows. Jpurnal of Dairy Science, 98:169-178.

Stojsin-Carter A, Mahboubi K, Costa NN, Gillis DJ, Carter TF, Neal MS, Miranda MS, Ohashi OM, Favetta LA, King WA. 2016. Systemic and local antiMullerian hormone reflects differences in the reproduction potential of Zebu and European type cattle. Anim Reprod Sci, 167:51-58.

Walsh SW, Mossa F, Butler ST, Berry DP, Scheetz D, Jimenez-Krassel F, Tempelman RJ, Carter F, Lonergan P, Evans ACO, Ireland JJ. 2014. Heritability and impact of environmental effects during pregnancy on antral follicle count in cattle. J Dairy Sci, 97:4503-4511.

Watanabe YF, Souza AH, Mingoti RD, Ferreira RM, Batista EOS, Dayan A, Watanabe O, Meirelles FV, Nogueira MFG, Ferraz JBS, Baruselli PS. 2017. Number of oocytes retrieved per donor during OPU and its relationship with in vitro embryo production and field fertility following embryo transfer. Anim Reprod, 14:635-644.

Wolfenson D, Inbara G, Rotha Z, Kaimb M, Blocha A, Braw-Tal R. 2004. Follicular dynamics and concentrations of steroids and gonadotropins in lactating cows and nulliparous heifers. Theriogenology, 62:10421055. 